\title{
Determinants of urban consumers' participation in informal vegetable markets: Evidence from Mahikeng, North West province, South Africa, and implications for policy
}

\begin{tabular}{|c|c|}
\hline \multicolumn{2}{|c|}{$\begin{array}{l}\text { Authors: } \\
\text { Olebogeng Marumo } \\
\text { Majola L. Mabuza }{ }^{1}\end{array}$} \\
\hline \multicolumn{2}{|c|}{$\begin{array}{l}\text { Affiliations: } \\
{ }^{1} \text { Department of Agricultural } \\
\text { Economics, North-West } \\
\text { University, South Africa }\end{array}$} \\
\hline \multicolumn{2}{|c|}{$\begin{array}{l}\text { Corresponding author: } \\
\text { Majola Mabuza, } \\
\text { Imabuza@yahoo.co.uk }\end{array}$} \\
\hline \multicolumn{2}{|c|}{$\begin{array}{l}\text { Dates: } \\
\text { Received: } 08 \text { Jan. } 2017 \\
\text { Accepted: } 13 \text { Dec. } 2017 \\
\text { Published: } 12 \text { Apr. } 2018\end{array}$} \\
\hline \multicolumn{2}{|c|}{$\begin{array}{l}\text { How to cite this article: } \\
\text { Marumo, O. \& Mabuza, M.L., } \\
2018 \text {, 'Determinants of urban } \\
\text { consumers' participation in } \\
\text { informal vegetable markets: } \\
\text { Evidence from Mahikeng, } \\
\text { North West province, } \\
\text { South Africa, and implications } \\
\text { for policy', South African } \\
\text { Journal of Economic and } \\
\text { Management Sciences 21(1), } \\
\text { a1743. https://doi. } \\
\text { org/10.4102/sajems. } \\
\text { v21i1.1743 }\end{array}$} \\
\hline \multicolumn{2}{|c|}{$\begin{array}{l}\text { Copyright: } \\
\text { (c) 2018. The Authors. } \\
\text { Licensee: AOSIS. This work } \\
\text { is licensed under the } \\
\text { Creative Commons } \\
\text { Attribution License. }\end{array}$} \\
\hline \multicolumn{2}{|l|}{ Read online: } \\
\hline 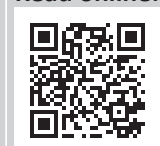 & $\begin{array}{l}\text { Scan this QR } \\
\text { code with your } \\
\text { smart phone or } \\
\text { mobile device } \\
\text { to read online. }\end{array}$ \\
\hline
\end{tabular}

Background: This article seeks to examine the perceptions of urban dwellers towards participating in informal vegetable markets and determine the underlying factors shaping their decisions to participate in such markets.

Aim and setting: The objectives were achieved by using cross-sectional data obtained from a random sample of 230 households from Mahikeng in the North West province of South Africa. Households' perceptions were measured using numeric responses to several questions, which covered various issues related to vegetable marketing and consumption. Principal component analysis (PCA) was employed to draw dominant perceptions from the set of responses.

Method: The probit model was used to determine factors influencing households' decisions of whether or not to participate in informal vegetable markets. Explanatory variables included demographic and socio-economic factors as well as perception-related factors, which were proxied by the dominant principal components (PCs) obtained from the PCA results.

Results: Two PCs were found dominant, representing safety and quality perceptions as well as the convenience and bargaining opportunities provided by informal traders. The probit regression results indicated that households' preference for the informal vegetable market were positively influenced by age of household head, low level of education of adult household members, and convenience provided by informal markets. However, households' wealth status and the perceptions on safety and quality of vegetables were found to have a significant negative influence on participation in the informal market.

Conclusion: Given that informal vegetable trade forms an integral part of the urban economy by offering easy access to food in public spaces and connecting with the formal economy where informal traders source their supplies, the study concludes by highlighting policy interventions aimed at improving the quality of food traded in the informal sector.

\section{Introduction}

Consumers in urban areas generally access fruits and vegetables from two primary sources. These are formal and informal markets. Formal markets are described by Rajiv (2010) as those outlets that are characterised by high quality produce and food safety standards and where the activities of marketing agents can be monitored with relative ease. Operations in such markets are also regulated by law and owners are subjected to annual tax payments. Examples of formal market outlets include supermarket chain stores and retail outlets that specialise in fruits and vegetables. Informal markets, however, are found in temporary settings and are not regulated or protected by law. Their operators also do not pay tax (Roesel \& Grace 2015). Examples of informal markets include street hawkers and traders who buy agricultural products from the formal markets in bulk for onward sales through informal channels (Potts 2008). Urban dwellers are more likely to purchase these than produce fruits and vegetables, given the opportunity cost of labour as most of them are engaged in salary or wage employment. In addition, while urban agriculture could have a role to play as a source of food for urban dwellers (see for example Smart, Nel \& Binns 2015), this may not be attainable due to land constraints and the existence of by-laws that prohibit certain agricultural activities in some municipalities (Frayne, Mccordic \& Shilombeleni 2014; Prain \& LeeSmith 2010). Given such limitations, urban dwellers find themselves with fewer options other than to access fruits and vegetables from the formal or informal sources of supply. 
Between the two main sources of fruits and vegetables supply, the informal sector seems to be gaining popularity in urban South Africa (Battersby 2011; Jackson 2010; Van Rooyen, Mavhandu \& Van Schalkwyk 1997). The emergence of this sector, as observed by Van Rooyen et al. (1997) and Peyton, Mosely and Battersby (2015), is linked to the inability of the formal sector to serve township markets as outlets such as supermarkets are often incompatible with consumption strategies of poor households. In the South African context, informal vegetable markets have several advantages, including the improvement of food security in the urban sector, particularly in high-density areas such as townships (Peyton et al. 2015). By virtue of being consumer oriented, informal markets are demand driven and provide a valuable source of income for many township dwellers (Van Rooyen et al. 1997). With South Africa experiencing an unemployment rate of about $24 \%$ (Statistics South Africa 2015a), which is largely linked to the decline in the labour absorption capacity of the formal economy, the informal sector which currently accounts for about 2.5 million jobs (Statistics South Africa 2015b) could be used to create opportunities in urban areas. Therefore, policy interventions targeted at improving informal market are likely to bring more positive changes in the economy. For instance, besides improving the welfare of market actors, interventions in the informal market could also advance the food security situation for urban dwellers. However, prior to making specific policy suggestions in this regard, it is important to analyse the socio-economic situation that may determine the long-term sustainability of informal vegetable markets in urban areas. Informal vegetable markets will be viable as long as there is substantial consumer demand from urban dwellers. To this end, it is essential to first understand what factors condition urban consumers' choice of vegetable retail outlets. Ngiba et al. (2009) indicates that very few studies have been conducted in South Africa in this regard; hence, this study is an attempt to address this research gap.

Outside South Africa, with the exception of Maruyama and Trung (2010), Okello et al. (2012) and Kapoor and Kumar (2015), studies in this area have been very scant. This study, however, differs from previous attempts by exploring a different methodological approach. For instance, while Maruyama and Trung (2010) and Okello et al. (2012) highlighted the importance of consumer perceptions in shaping their choices of point of purchase, the perception variables in their analytical models were predetermined, an approach that could have influenced the ultimate results. Households' perceptions in this study were captured using numeric responses to several questions, which covered a number of contextual issues related to the two alternative markets. Principal component analysis (PCA) was then applied to extract dominant perception-related factors that were subsequently used as explanatory variables in a discrete choice model to determine their effects on the respondents' choices of vegetable market outlets. Kapoor and Kumar (2015) did not include perception-related factors in their discrete choice model despite their importance in shaping consumer decisions. In addition, perceptions are usually influenced by past experiences; hence, the inclusion of perception-related variables in a discrete choice model, as was done by Maruyama and Trung (2010) and Okello et al. (2012), could lead to problems of endogeneity (Bontemps \& Nauges 2016). This study, therefore, further differs from previous attempts in that exogeneity tests were conducted to ascertain the validity of the empirical findings.

Specifically, this study attempted to: (1) examine the perceptions held by urban consumers towards informal vegetable markets and (2) determine the underlying factors influencing urban consumers to purchase vegetables from either formal or informal points of sale. The above objectives were achieved by using evidence from the Ngaka Modiri Molema District Municipality in Mahikeng, North West province. Mahikeng has experienced significant expansion of supermarket chain stores as well as fruit and vegetable specialty outlets. In addition, it has a large concentration of consumers with varied socio-economic attributes that have made both formal and informal vegetable trade relevant. The rest of the article proceeds as follows: the next section provides a succinct review of the literature, followed by an outline of the methods and procedures. This section is followed by the empirical results while the last section presents the conclusions and implications for policy.

\section{Literature review}

Vegetable trade in most developing countries has for many years been dominated by on-farm and informal points of sale, particularly open-air and roadside markets. However, in recent years food retailing (including fruits and vegetables) has seen the emergence and rapid growth of non-traditional or formal outlets such as supermarkets and specialty stores (Weatherspoon \& Reardon 2003). The literature identifies various geographic and socio-economic factors responsible for supermarket diffusion in developing countries (Crush \& Frayne 2011; Seto \& Ramankutty 2016). In areas characterised by spatial separation of socio-economic groups, supermarket operators normally prioritise higher-income areas. However, in areas with no spatial separation of economic groups, supermarkets are accessible even to lower-income consumers, even though their use may not be the same (Okello et al. 2012). For instance, given that major supermarkets carry elaborate grocery sections that feature a wide variety of fresh agricultural produce, some consumers find multi-stop shopping in many small stores more costly than the one-stop shopping in such supermarkets (Goldman \& Hino 2005). For households with access to reliable transport and proper storage for larger food quantities, sourcing vegetable supplies from supermarkets becomes even more cost effective (Crush \& Frayne 2011).

The procurement of perishables from supermarkets can also be linked to the increased demand for fresh supplies with specific quality attributes by consumers, particularly in the urban areas (Minten \& Reardon 2008). These are consumers with high 
purchasing power who have become more selective with regard to quality and source of food. Therefore, they source their supplies from outlets they consider safe or perceive to offer quality food. Such consumers are more particular about the source of food given the increased awareness of the medical health dangers of consuming foods grown using unsafe practices as well as the widespread food safety scandals (Wongprawmas, Canavari \& Waisarayutt 2014).

Okello et al. (2012) indicate that despite the changing nature of fresh vegetable retailing in developing countries, particularly in sub-Saharan Africa, informal points of sale have remained significant for many urban dwellers who have resisted the enticement of modernity. In conformity, Goldman and Hino (2005) indicate that in some instances, lower-income consumers who purchase small amounts and shop frequently get lower benefits from shopping in supermarkets. While this may not be apparent to some researchers, such consumers put high value on attributes associated with small informal outlets, such as personal attention by store owners and operators, social interactions during shopping and being part of an informal economy centred around these outlets. Roesel and Grace (2015) add that through the social capital that develops from constant interactions, informal traders can exchange their products with consumers on credit. Other consumers are reported by Goldman, Ramaswami and Krider (2002) to use supermarkets for selected items while they rely on informal markets for perishable commodities like vegetables. Such consumption behaviour could be related to the underdeveloped and fragmented supply system for perishable foods or supermarkets' space limitations, particularly in developing countries. As a result, some supermarkets could end up offering a limited variety and quality compared to the traditional or informal sector. Goldman, Krider and Ramaswami (1999) also attribute the limited use of supermarkets for perishable products to cultural values, which determine consumers' attitudes towards food and their own definition of 'quality' and 'freshness'. For instance, some consumers may prefer meat from recently slaughtered animals to frozen meat normally found in supermarkets (Roesel \& Grace 2015).

\section{Methods and procedures Empirical model}

Past studies (e.g. Lichtenstein, Netemeyer \& Burton 1990; Meng et al. 2014) provide a natural setting within which consumers' decisions to purchase similar commodities from alternative points of sale can be analysed. The choice between formal and informal markets as a source of vegetable supply is based on consumers' utility maximisation. Given that the decision to purchase from either of the two markets is dichotomous, a probit model was used for analysis (Maddala 1983). To construct the dependent variable, respondents were asked to indicate their most preferred point of sale for vegetables. The options were presented as follows: $1=$ Pick n Pay, 2 = Spar, 3 = Fruit \& Veg (Food Lover's Market), $4=$ Shoprite, 5 = Hawkers, $6=$ Roadside stands, $7=$ Door-to- door, 8 = Spaza shop, and $9=$ Farmers day, where options $1-4$ constitute the formal market while options 5-9 constitute the informal market.

The literature suggests that households' purchasing decisions can be shaped by demographic, socio-economic attributes, and perceptions (Carpenter \& Moore 2006; Meng et al. 2014; Okello et al. 2012). For this study, the demographic attributes that were considered include age and gender of household head, proportion of adult household members (18-60 years) with primary, secondary, matric or tertiary education, household size (in adult-equivalents), effective dependency ratio, and race. Consideration of other household members with regard to education was based on previous evidence (e.g. Mabuza et al. 2016) where it was found that in a typical African household, members who have come of age can, in various ways (e.g. physically, financially, psychologically, or otherwise), influence the household's purchasing behaviour and food security direction. Socio-economic factors considered in the model included main sources of income (e.g. salary or wage, selfemployment, or grant) and wealth. The variable for wealth, which was in continuous form, was computed from an estimated value (in rands) of household assets that were identified by the respondents. The decision to use a wealth variable, as opposed to income, was based on the fact that most households are generally not comfortable with sharing financial information.

Following evidence from the literature (e.g. Goldman, Ramaswami \& Krider 2002; Maruyama \& Trung 2010; Okello et al. 2012), an additional variable was included in the model to account for the influence of consumers' perceptions towards the two alternative main sources of vegetable supply. Perceptions can either develop from gaining information or from one's previous experience with vegetable markets. Households' perceptions were captured using numeric responses to 11 questions, which covered a number of contextual issues related to the two alternative markets (see Table 2). Principal component analysis was then applied to extract composite measures of perceptions from the responses, which were subsequently used as explanatory variables in the discrete choice model. The perception variables were measured in 5-point Likert-type scale. Two prominent principal components (PCs) were identified by showing eigenvalues greater or equal to 1. PC1 was found to represent safety and quality perceptions whereas PC2 was found to represent convenience and bargaining opportunities. Principal component analysis results are presented in Table 2 and discussed in the section 'Urban households' perceptions on informal vegetable markets'.

Given that the respondents' perceptions on informal markets could be shaped by previous experiences, there is a possibility that perceptions are endogenous (Bontemps \& Nauges 2016). In view of the above likelihood, exogeneity was tested by estimating two Stata ivprobit models where the perception variables were respectively instrumented by 
the frequency of purchase of 14 vegetables that were commonly consumed by the respondents. For each vegetable, frequency of purchase was measured as follows: $0=$ never, 1 = seldom (1-2/month), 2 = sometimes (1-2/week), $3=$ often ( $3-4 /$ week), and $4=$ daily. Therefore, given that there were 14 commonly consumed vegetables, each household had a variable generated as a score out of 56, which was labelled 'frequency of purchase'. The choice of this variable was premised on evidence from Goldman and Hino (2005) that consumers' perceptions on food markets develop from past experiences with the respective markets. The reliability of the instrument was ascertained by applying Di Falco, Veronesi and Yesuf's (2011) falsification test, where the results indicated that the selected instrument was valid. The instrumental variable was statistically significant in explaining the households' perceptions $(F=3.41[p=0.06]$ - first equation [quality perception]) and $(F=6.09$ [ $p=0.014]$ - second equation [convenience and bargaining perception]), but not statistically significant in explaining the respondents' choice between the formal and informal points of vegetable sale $\left(\operatorname{LR} \chi^{2}=0.19[p=0.663]-\right.$ first equation) and $\left(\mathrm{LR} \chi^{2}=0.24[p=0.623]-\right.$ second equation). However, with both ivprobit models yielding non-significant $\chi^{2}$ values for the Wald test of exogeneity $\left(\chi^{2}=0.47[p=0.492]\right.$ - first equation $)$ and $\left(\chi^{2}=0.04[p=0.838]\right.$ - second equation), it was concluded that perception factors were not endogenous in this study. Therefore, the 'ordinary' probit model, whose results are presented in the 'Results and discussion' section, was used to identify the factors influencing households' decisions to purchase vegetables from either the formal or informal market. All estimations were conducted on Stata 13.

\section{Sampling and data collection procedure}

The study was carried out in 2015 in Mahikeng Local Municipality, situated in the North West province of South Africa. The municipality has 18701 urban households, which are divided into 25 sections (Statistics South Africa 2011). This study, however, used $60 \%$ of the urban areas, which were selected randomly. Having applied the Krejcie and Morgan (1970) procedure, a sample size of 370 households was selected for cross-sectional data gathering through the use of a structured questionnaire. The number of sampled households from each location was estimated with probability proportional to population size. Through the assistance of 11 trained enumerators, data were obtained through face-to-face interviews with household heads between July and September 2015. However, due to some households not being willing to participate in the survey, a total of 230 questionnaires were eventually analysed. Given that one of the specific objectives of the study was to measure consumers' perceptions on informal vegetable markets, reliability of the questionnaire had to be ascertained. To this end, test-retest reliability was conducted during the pretesting phase. It was during this phase that some questions had to be revised so that the captured data would help achieve the objectives of the study.

\section{Results and discussion}

This section has three sub-sections: the descriptive statistics for variables used in the discrete choice model are presented first, followed by a discussion of the PCA results. The last subsection presents the empirical results of the probit regression model.

\section{Demographic and socio-economic description of respondents}

Table 1 presents descriptive statistics of variables used in the probit regression model. The results indicate that with respect to gender, age group, race, household size, and major sources of income, households that preferred to purchase vegetables from the two markets had no statistically significant differences from one another. With respect to race, over $80 \%$ of the respondents were black South Africans and the remainder were mixed race South Africans, Indian South Africans and white South Africans, respectively. In terms of the choices of vegetable sources, the results indicate that all races had more preference for the formal market while none of the white respondents showed preference for the informal market.

However, in terms of dependency ratio, households that were more likely to opt for the informal market had more members who were unemployed and generated less or no income at all. Consequently, such households were more likely to opt for a source that offers vegetables at a relatively lower price. These findings were confirmed by the variable for wealth (proxy for household income). Table 1 also indicates that wealthy households preferred to source their vegetables from the formal market as opposed to the informal one. Households that bought from the two predominant sources were also found to differ significantly in terms of the educated proportion of adult members as well as their perceptions on informal markets.

\section{Urban households' perceptions on informal vegetable markets}

Presented in this subsection are the PCA results, which gave an indication of consumers' perceptions on informal vegetable markets in the study area.

Given that the perception variables were measured in the same unit (5- point Likert-type scale), PCA was applied using a covariance matrix (Krzanowski 1987). The results presented in Table 2 indicate that the use of PCA was found appropriate to provide significant reductions in dimensionality as evidenced by the Kaiser-Meyer-Olkin and Bartlett's test of sphericity. Having applied the Kaiser criterion of retaining PCs with eigenvalues 1 or greater, two PCs, which together accounted for $52 \%$ of total variation in the original variables, were retained and later used in the probit model as explanatory variables. Applying the rule of thumb proposed by Koutsoyiannis (1992) for observations above 50, PC loadings greater than $|0.30|$ were considered to indicate a strong association between the original scores and the PCs. These loadings are highlighted in Table 2 in bold print. 
TABLE 1: Descriptive statistics of variables used in the probit regression model, $2015(n=230)$.

\begin{tabular}{|c|c|c|c|c|c|}
\hline Variable (A) & (B) Unit & $\begin{array}{l}\text { (C) \% of total sample } \\
(n=230)\end{array}$ & $\begin{array}{l}\text { (D) \% of (C) from formal } \\
(n=176)\end{array}$ & $\begin{array}{l}(E) \% \text { of }(C) \text { from informal } \\
(n=54)\end{array}$ & $\chi^{2}$ \\
\hline \multicolumn{6}{|l|}{ Categorical } \\
\hline Gender of household head & Male & 64.35 & 77.03 & 22.97 & 0.06 \\
\hline Age of household head (18-35 years) & Yes & 23.48 & 74.07 & 25.93 & 0.23 \\
\hline Age of household head ( $36-45$ years) & Yes & 72.61 & 75.45 & 24.55 & 0.39 \\
\hline Age of household head (45-59 years) & Yes & 61.30 & 77.30 & 22.70 & 0.12 \\
\hline Race of household - Black & Yes & 84.78 & 76.41 & 23.59 & 0.01 \\
\hline Race of household - White & Yes & 2.61 & 100 & 0 & 1.89 \\
\hline Race of household - Indian & Yes & 3.04 & 71.43 & 28.57 & 0.10 \\
\hline Race of household - Mixed race & Yes & 9.57 & 72.73 & 27.27 & 0.19 \\
\hline Salary is a major source of household income & Yes & 76.52 & 76.70 & 23.30 & 0.01 \\
\hline Social grant is a major source of household income & Yes & 6.09 & 71.43 & 28.57 & 0.22 \\
\hline Self-employment is a major source of household income & Yes & 17.39 & 77.50 & 22.50 & 0.03 \\
\hline Continuous & Unit & $\begin{array}{l}\text { Mean total sample } \\
(n=230)\end{array}$ & $\begin{array}{l}\text { Mean formal } \\
(n=176)\end{array}$ & $\begin{array}{l}\text { Mean informal } \\
(n=54)\end{array}$ & $t$ \\
\hline Age of household head & Years & 44.67 & 44.74 & 44.42 & 0.03 \\
\hline Household size & Adult equivalent & 2.74 & 2.75 & 2.72 & 0.01 \\
\hline Effective dependency ratio & Percentage & 1.03 & 0.95 & 1.22 & $2.78^{*}$ \\
\hline $\begin{array}{l}\text { Proportion of household members } \\
\text { (18-64 years) with primary education }\end{array}$ & Percentage & 0.12 & 0.11 & 0.17 & $4.82 * *$ \\
\hline $\begin{array}{l}\text { Proportion of household members } \\
\text { (18-64 years) with secondary education }\end{array}$ & Percentage & 0.21 & 0.19 & 0.27 & $4.55 * *$ \\
\hline $\begin{array}{l}\text { Proportion of household members } \\
\text { (18-64 years) with tertiary education }\end{array}$ & Percentage & 0.49 & 0.53 & 0.38 & $8.84 * * *$ \\
\hline Wealth (value of household assets) & Rand $\dagger$ & 245623 & 271745 & 160498 & $5.66 * *$ \\
\hline Perception - Safety and quality & PC_1 & 1.73 & 2.06 & 0.69 & $19.58 * * *$ \\
\hline Perception - Bargaining and convenience & PC_2 & 7.93 & 7.84 & 8.26 & $4.78 * *$ \\
\hline
\end{tabular}

$* * *, * *, *$ Denote significance at the $1 \%, 5 \%$, and $10 \%$ levels of probability, respectively.

$\dagger, 1$ US\$ = R13.90 as at 15 October 2016 (South African Reserve Bank).

TABLE 2: Principal component analysis of urban households' perceptions on informal vegetable markets, $2015(n=230)$.

\begin{tabular}{|c|c|c|c|c|}
\hline \multirow[t]{2}{*}{ Variables $\dagger$} & \multirow[t]{2}{*}{ Variable label } & \multirow[t]{2}{*}{ Mean value } & \multicolumn{2}{|c|}{ Principal components } \\
\hline & & & $\begin{array}{l}\text { 1: Safety and quality - } \\
\text { Component loadings }\end{array}$ & $\begin{array}{l}\text { 2: Bargaining and convenience } \\
\text { - Component loadings }\end{array}$ \\
\hline $\begin{array}{l}\text { Vegetables sold through informal and formal markets are sourced } \\
\text { from the same suppliers }\end{array}$ & D1 & 3.06 & -0.2258 & 0.2327 \\
\hline IVMs fill the gap of food insecurity at household level & D2 & 3.97 & -0.1740 & 0.3035 \\
\hline IVMs allow consumers to bargain & D3 & 3.81 & -0.0730 & 0.4905 \\
\hline IVMs are always available when we need supplies & D4 & 3.58 & -0.1937 & 0.4317 \\
\hline Traders in the IVMs are untidy & D6 & 3.03 & 0.4546 & 0.1377 \\
\hline The facilities in IVMs are poor and not hygienic & D7 & 3.06 & 0.3954 & 0.3938 \\
\hline Vegetables from IVMs are normally fresh & D8 & 3.32 & -0.2543 & -0.2185 \\
\hline Vegetables from IVMs are damaged and not appealing & D9 & 2.83 & 0.4294 & 0.1451 \\
\hline $\begin{array}{l}\text { Because nobody monitors these traders, their vegetables are likely to be } \\
\text { substandard and a health hazard }\end{array}$ & D10 & 2.94 & 0.3752 & -0.0427 \\
\hline Vegetables in IVMs have no labels, hence they are not trustworthy & D11 & 2.73 & 0.2787 & -0.0166 \\
\hline Eigenvalues & - & - & 4.2472 & 1.5374 \\
\hline Proportion of variance explained & - & - & 0.3784 & 0.1370 \\
\hline Cumulative proportion of variance explained & - & - & 0.3784 & 0.5153 \\
\hline
\end{tabular}

Note: Bartlett's test of sphericity chi-value $=749.824 *$ Kaiser-Meyer-Olkin measure of sampling adequacy $=0.806 ;$ Cronbach's alpha $=0.865$.

IVM, informal vegetable market.

$*$, denotes significance at the $1 \%$ level of probability.

$\dagger, 5=$ strongly agree; 4 = agree; $3=$ not sure; 2 = disagree; and $1=$ strongly disagree

The first PC in Table 2 was found to represent safety and quality perceptions. Accounting for $38 \%$ of the total variation in the original variables, the dominant indicators for PC1 were D6, D7, D9 and D10. These results suggest that urban consumers' perceptions were largely influenced by the cleanliness of the environment from which the vegetables were sold as well as the quality of the vegetables themselves. PC2 was found to represent perceptions related to bargaining between buyers and sellers and the convenience that informal traders provide urban consumers. The dominant indicators for PC2 were D2, D3, D4, D5 and D7. However, D7 had more impact on PC1 than PC2. These results imply that urban consumers' perceptions on informal vegetable markets were also influenced by the fact that informal traders help them towards improving their food security status, allow them to bargain, and provide them with a comparatively less costly option of accessing vegetables consistently. 


\section{Factors influencing urban consumers' choice of vegetables sources of supply}

The probit regression results are shown in Table 3 and the discussion focuses on the factors that were found to have a significant influence on urban households' decision on whether or not to purchase vegetables from the informal markets. The overall estimated model was statistically significant as the estimated Wald $\chi^{2}$ value was significant at the $1 \%$ level of probability. The model also correctly predicted about $80 \%$ of the households' decisions, suggesting that it fitted the data quite well. Prior to estimating the probit model, the variables were tested for possible multicollinearity using pairwise correlations and variance inflation factor (VIF). With the results indicating that the variables were reasonably independent of one another, the model was subsequently estimated with robust standard errors to address possibilities of heteroscedasticity.

Contrary to Okello et al's (2012) findings, the results in Table 3 indicate that households headed by relatively old people (members within the age bracket of 46-59 years in this case) were found to be significantly more likely to participate in the informal market. Available evidence (e.g. Sahyoun, Zhang \& Serdula 2006) specifies that as humans grow older, the consumption of healthy foods such as vegetables becomes more important. Older adults are at high risk of developing chronic conditions; therefore, prevention becomes a better option. As such, households headed by relatively old people may decide to purchase vegetables from a nearby convenient source, which in this case is the informal market. Another tentative reason behind this result is the fact that prices in the informal markets are comparatively low. Therefore, due to the high consumption need for vegetables, such households would prefer to purchase vegetables from sources that are capable of providing more in terms of quantity at a low retail price.

Another estimated coefficient that was found to be statistically significant was the proportion of adult household members with primary education. Households with a greater proportion of members in this category were more likely to participate in the informal as opposed to the formal vegetable market. In relation to this result, Table 3 further indicates that as adult members become exposed to further education, their decisions or willingness to participate in the informal vegetable market are likely to change. This was evidenced by the estimated coefficient for the proportion of adult household members with tertiary education which was positive. Although not statistically significant, this result,

TABLE 3: Probit estimates of factors influencing urban consumers' choice of vegetables source of supply in Mahikeng, $2015(n=230)$.

\begin{tabular}{|c|c|c|c|c|c|c|}
\hline \multirow[t]{2}{*}{ Variable } & \multirow[t]{2}{*}{ Coefficient } & \multirow{2}{*}{$\begin{array}{l}\text { Robust standard } \\
\text { error }\end{array}$} & \multicolumn{3}{|c|}{ Marginal values } & \multirow[t]{2}{*}{ VIF } \\
\hline & & & $\partial y / \partial x$ & Standard error & $z$ & \\
\hline \multicolumn{7}{|l|}{ Household demographics } \\
\hline $\begin{array}{l}\text { Dummy for gender of household head } \\
\text { (female }=1) \dagger\end{array}$ & -0.0013 & 0.2437 & -0.0003 & 0.0671 & -0.01 & 1.37 \\
\hline $\begin{array}{l}\text { Dummy for age of household head (18-35 } \\
\text { years) }(\text { Yes }=1) \dagger\end{array}$ & -0.8398 & 0.5537 & -0.2686 & 0.1939 & -1.39 & 2.53 \\
\hline $\begin{array}{l}\text { Dummy for age household head (36-45 } \\
\text { years) }(\text { Yes }=1) \dagger\end{array}$ & -0.6783 & 0.5667 & -0.2087 & 0.1890 & -1.10 & 2.97 \\
\hline $\begin{array}{l}\text { Dummy for age household head (46-59 } \\
\text { years) }(\text { Yes }=1) \dagger\end{array}$ & $-0.8972 *$ & 0.5383 & $-0.2645^{*}$ & 0.1645 & -1.64 & 3.05 \\
\hline Dummy for race of household (Black $=1) \dagger$ & 0.3091 & 0.2724 & 0.0926 & 0.0871 & 1.06 & 1.15 \\
\hline Household size (adult equivalent) & -0.0621 & 0.0958 & -0.0171 & 0.0265 & -0.64 & 2.00 \\
\hline Effective dependency ratio & 0.0155 & 0.1252 & 0.0042 & 0.0345 & 0.12 & 1.60 \\
\hline $\begin{array}{l}\text { Proportion of adult members ( } 18-64 \text { years) } \\
\text { with primary education }\end{array}$ & $-1.1994 *$ & 0.7147 & $-0.3304^{*}$ & 0.1956 & -1.69 & 1.61 \\
\hline $\begin{array}{l}\text { Proportion of adult members (18-64 years) } \\
\text { with secondary education }\end{array}$ & -0.5437 & 0.5364 & -0.1497 & 0.1469 & -1.02 & 1.80 \\
\hline $\begin{array}{l}\text { Proportion of adult members ( } 18-64 \text { years) } \\
\text { with tertiary education }\end{array}$ & 0.0886 & 0.4675 & 0.0244 & 0.1290 & 0.19 & 2.33 \\
\hline \multicolumn{7}{|l|}{ Socio-economic factors } \\
\hline $\begin{array}{l}\text { Dummy for salary as a major source of } \\
\text { income }(\text { Yes }=1) \dagger\end{array}$ & 0.1333 & 0.2818 & 0.0378 & 0.0825 & 0.46 & 1.49 \\
\hline $\begin{array}{l}\text { Dummy for elderly grant as a major source } \\
\text { of income (Yes }=1) \dagger\end{array}$ & -0.6953 & 0.6215 & -0.2345 & 0.2368 & -0.99 & 2.09 \\
\hline Wealth (value of household assets in rand) & $1.06 \mathrm{e}-06 * *$ & $5.10 \mathrm{e}-07$ & $2.93 \mathrm{e}-07^{* *}$ & 0.0000 & 2.11 & 1.23 \\
\hline \multicolumn{7}{|l|}{ Perceptions } \\
\hline Safety and quality (PC_1) & $0.2073 * * *$ & 0.0519 & $0.0571 * * *$ & 0.0141 & 4.05 & 1.16 \\
\hline Bargaining and convenience (PC_2) & $-0.1437 *$ & 0.0805 & $-0.0396 *$ & 0.0219 & -1.80 & 1.06 \\
\hline Constant & $2.1620 * *$ & 1.0151 & - & - & - & - \\
\hline Observations & 230 & - & - & - & - & - \\
\hline Wald $\chi^{2}$ (15 df) & $38.57 * * *$ & - & - & - & - & - \\
\hline Pseudo $R^{2}$ & 0.1578 & - & - & - & - & - \\
\hline Correct classification & $80.43 \%$ & - & - & - & - & - \\
\hline Log pseudolikelihood & -105.56632 & - & - & - & - & - \\
\hline
\end{tabular}

VIF, variance inflation factor.

$\dagger, \partial y / \partial x$ is discrete change from 0 to 1 .

$* * *, * *, *$ Denote significance at the $1 \%, 5 \%$, and $10 \%$ levels of probability, respectively. 
which conforms to previous findings (e.g. Kapoor \& Kumar 2015; Meng et al. 2014), implies that with further education, urban households would prefer to purchase their vegetables from the formal market. Better educated household members are more likely to have improved access to market-related and food information that significantly influences their decision-making. Better educated members could also be earning relatively high salaries; hence, they can afford to source food supplies from the formal market.

The estimated coefficient for wealth was found to be positively and statistically significantly related to households' participation in the formal as opposed to informal vegetable market. Wealthy households are more capable of paying the price premium charged by formal vegetable outlets for food safety and quality as well as labelling. Table 3 further indicates that the two estimated coefficients for households' perceptions on informal vegetable markets were both statistically significant. The results indicate that households that are mostly concerned about food safety and quality are significantly less likely to participate in the informal vegetable market. However, households that prefer to bargain when they purchase vegetables were found to be significantly more likely to purchase their vegetables from the informal market. By virtue of trading in highly perishable commodities, which are usually displayed in the open as opposed to refrigerated containers, informal traders are more likely to bargain with their customers as they intend to sell their stock within the shortest possible time. If the vegetables remain unsold for a number of consecutive days, they will lose form and end up being sold at very low prices or discarded due to spoilage. Related to bargaining is the issue of convenience. This factor is also important considering that most informal vegetable outlets are located along roadsides that urban dwellers use especially when travelling to and from work. Some are within residential places rather than in the central business district, while others are mobile enough to do door-to-door sales, making it very convenient for the consumer who ends up saving on transport costs.

An attempt was made to find out from the respondents if they were likely to change their preferred market outlets for future purchases, particularly in the wake of food scares linked to vegetables. The responses revealed that the number of consumers who would prefer the formal market under the circumstances increased from 176 to 194 while 36 indicated that irrespective of such food scares, they would remain loyal to the informal market. This underlines that, ceteris paribus, vegetables sold through formal channels are generally perceived to be consistent in quality.

Despite the fact that over $75 \%$ of the sampled households indicated that most of their vegetables are sourced from the formal market, the study accentuates the importance of informal vegetable markets in the urban sector. It also underlines that the main characteristic of food security in urban areas is not food production, but access to food. Accessibility hinges primarily on the household's ability to purchase, which in turn depends on household income, the price of food and location of food outlets. So, if informal markets are valued by urban vegetable consumers, how can informal traders be assisted to address the food safety and quality concerns raised by respondents, and whose responsibility is this? Worth indicating is that the municipality has tried over the years to have informal fruit and vegetable traders work collectively so that whatever programmes meant to assist them are coordinated easily. In some instances, fixed stalls have been erected in certain locations where traders are expected to pay a nominal monthly fee for maintaining the facilities. However, because informal traders have neglected these facilities, instead electing to conduct their businesses in strategic areas where they can easily make contact with consumers, working as a collective seems to suppress their entrepreneurial abilities.

\section{Limitations of the study and areas for further research}

This study focused on urban consumers, but did not factor in the concerns and circumstances of informal traders. Given the above, further research is required, perhaps to study the perceptions of urban-based informal vegetable traders on the sustainability of their economic activities in the light of consumers' food safety and quality concerns. The proposed study would also provide information on how informal traders would prefer to be capacitated so that they not only assume a position where they are able to address consumers' concerns, but manage to increase their market share in an industry that continues to be monopolised by supermarket chain stores. In addition, a risk pathway analysis along the informal vegetable chain, compared with the formal market is recommended. The novelty of the proposed risk pathway analysis emanates from the observation that a considerable percentage of the vegetables traded in the South African informal market are either sourced from the formal market or the same primary suppliers (see Jackson 2010 for details). Another interesting dimension linked to the proposed risk pathway analysis relates to recent findings reported by Roesel and Grace (2015), where food sold through formal markets in east and southern Africa, though commonly perceived to be safer, had lower compliance with standards than informally marketed food.

\section{Conclusions and implications for policy}

The study sought to examine the perceptions of urban dwellers towards participating in informal vegetable markets and determine the underlying factors shaping their purchasing decisions. These specific objectives were addressed by using cross-sectional data obtained through the use of a questionnaire from a sample of 230 households that were identified through a multi-stage random sampling technique. Having used PCA to analyse consumers' perceptions on vegetable markets, two PCs were found to be dominant, representing safety and quality perceptions as well as the convenience and bargaining opportunity provided 
by informal traders. The probit regression results suggested that households' preference for the informal vegetable market were positively influenced by age of household head, low level of education of adult household members, and the convenience provided by informal markets. Households that fall under the low-income bracket and are headed by relatively old members were found to have difficulty in accessing the formal market, which provides vegetables at a comparatively high price. Besides the price premium, which is linked to the quality and labelling of supplies in the formal sector, given the location of most of the supermarket chain stores, consumers have to incur additional transport costs in their attempt to access vegetables sold through the formal market. In contrast, convenient delivery and lower prices (reflecting lower handling and processing costs) that characterise informal markets are the principal benefits for consumers. However, households' wealth status and the perceptions on safety and quality of vegetables were found to have a significant negative influence on participation in the informal market.

Given that informal vegetable trade forms an integral part of the urban economy by offering easy access to food in public spaces and connecting with the formal economy where informal traders source their supplies, policy interventions are required to improve their circumstances and the quality of the food they sell. To achieve the above, it is important that the role played by the informal sector is first recognised at the national government level. Currently, the South African government does recognise the employment creation capacity of the informal sector. However, national initiatives such as the National Development Plan do not have defined and explicit programmes on how existing informal sector operators will be supported so that they reach a stage where they are better organised and can swiftly respond to market requirements. This is one area that needs to be addressed as a matter of priority.

Secondly, reflecting on the results of this study, it is recommended that through the National Informal Business Upliftment Strategy, currently being driven by the Department of Small Business Development, an integrated programme should be introduced to provide the necessary capacity to informal food traders to improve their services, particularly on matters related to food quality. Such initiatives can go a long way in improving the value of their businesses while ensuring urban food and nutrition security.

\section{Acknowledgements}

The authors are grateful to the NWU Food Security and Safety Niche Area as well as the FAST Research Committee for funding different aspects of the study. The opinions expressed in this paper are those of the authors and do not necessarily reflect the views of the funders, North-West University; Food Security and Safety Niche Area and the FAST Research Committee Fund.

\section{Competing interests}

The authors declare that they have no financial or personal relationships that may have inappropriately influenced them in writing this article.

\section{Authors' contributions}

O.M. was the lead researcher. He identified the research gap, was responsible for data gathering, analysis and write-up. All this he did under the technical guidance and supervision of M.L.M. who provided comments and suggestions on every stage of the research process and edited different draft versions of this article.

\section{References}

Battersby, J., 2011, 'Urban food insecurity in Cape Town, South Africa: An alternative approach to food access', Development Southern Africa 28, 545-561. https://doi. org/10.1080/0376835X.2011.605572

Bontemps, C. \& Nauges, C., 2016, 'The impact of perceptions in averting-decision models: An application of the special regressor method to drinking water choices', American Journal of Agricultural Economics 98(1), 297-313. https://doi. org/10.1093/ajae/aav046

Carpenter, J. \& Moore, M., 2006, 'Consumer demographics, store attributes, and retail format choice in the US grocery market', International Journal of Retail and Distribution Management 34(6), 434-452. https://doi.org/10.1108/0959055 Distribution
0610667038

Crush, C. \& Frayne, B., 2011, 'Supermarket expansion and the informal food economy in Southern African cities: Implications for urban food security', Journal of Southern African Studies 37(4), 781-804. https://doi.org/10.1080/03057070.201 1.617532

Di Falco, S., Veronesi, M. \& Yesuf, M., 2011, 'Does adaptation to climate change provide food security? A micro-perspective from Ethiopia', American Journal of Agricultural Economics 93(3), 829-846. https://doi.org/10.1093/ajae/aar006

Frayne, B., Mccordic, C. \& Shilombeleni, H., 2014, 'Growing out of poverty: Does urban agriculture contribute to household food security in Southern African cities?', Urban Forum 25(2), 177-189. https://doi.org/10.1007/s12132-014-9219-

Goldman, A., Krider, R.E. \& Ramaswami, S., 1999, 'The persistent competitive advantage of traditional food retailers in Asia: Wet markets' continued dominance in Hong Kong', Journal of Macromarketing 19(2), 126-139. https://doi. org/10.1177/0276146799192004

Goldman, A. \& Hino, H., 2005, 'Supermarkets vs. traditional retail stores: Diagnosing the barriers to supermarkets' market share growth in an ethnic minority community', Journal of Retailing and Consumer Services 12(4), 273-284. https:// doi.org/10.1016/j.jretconser.2004.10.002

Goldman, A., Ramaswami, S. \& Krider, R.E., 2002, 'Barriers to the advancement of modern food retail formats: Theory and measurement', Journal of Retailing 78(4), 281-295. https://doi.org/10.1016/S0022-4359(02)00098-2

Jackson, A.L., 2010, 'The complex food system: A case study of soft vegetables produced in the Philippi horticultural area and the soft vegetables purchased at different links in the food system', MSc thesis, University of Cape Town.

Kapoor, S. \& Kumar, N., 2015, 'Fruit and vegetable consumers' behavior: Implications for organized retailers in emerging markets', Journal of International Food and Agribusiness Marketing 27(3), 203-227. https://doi.org/10.1080/08974438.2014 Agribusiness 940118

Koutsoyiannis, A., 1992, Theory of econometrics, 2nd edn., Macmillan Education Limited, Hampshire.

Krejcie, R.V. \& Morgan, D.W., 1970, 'Determining sample size for research activities', Educational and Psychological Measurement 30, 607-610. https://doi. org $/ 10.1177 / 001316447003000308$

Krzanowski, W.J., 1987, 'Cross-validation in principal component analysis', Biometrics 43(3), 75-584. https://doi.org/10.2307/2531996

Lichtenstein, R., Netemeyer, R.G. \& Burton, S., 1990, 'Distinguishing coupon proneness from value consciousness: An acquisition-transaction utility theory perspective', Journal of Marketing 54(3), 54-67. https://doi.org/10.2307/1251816

Mabuza, M.L., Ortmann, G.F., Wale, E. \& Mutenje, M.J., 2016, 'The impact of major income sources on rural household food (in)security: Evidence from Swaziland and implications for policy', Ecology of Food and Nutrition 55(2), 209-230. https:// and implications for policy', Ecology of Food
doi.org/10.1080/03670244.2015.1121482

Maddala, G.S., 1983, Limited-dependent and qualitative variables in econometrics, Cambridge University Press, New York.

Maruyama, M. \& Trung, L.V., 2010, 'The nature of informal food bazaars: Empirical results for Urban Hanoi, Vietnam', Journal of Retailing and Consumer Services 17 1-9. https://doi.org/10.1016/j.jretconser.2009.08.006 
Meng, T., Florkowski, W.J., Sarpong, D.B., Chinnan, M.S. \& Resurreccion, A.V.A., 2014 'Consumer's food shopping choice in Ghana: Supermarkets or traditional outlets?', International Food and Agribusiness Management Review 17, 107-129.

Minten, B. \& Reardon, T., 2008, 'Food prices, quality, and quality's pricing in supermarkets versus traditional markets in developing countries', Applied Economic Perspectives and Policy 30(3), 480-490. https://doi.org/10.1111/j.1467-9353.2008. 00422.x

Ngiba, C.N., Dickinson, D., Whittaker, L. \& Beswick, C., 2009, 'Dynamics of trade between the formal sector and informal traders: The case of fruits and vegetable sellers at Natalspruit market, Ekurhuleni', South African Journal of Economic and Management Sciences 12(4), 462-474. https://doi.org/10.4102/sajems. v12i4.189

Okello, J.J., Lagerkvist, C.J., Hess, S., Ngigi, M. \& Karanja, N., 2012, 'Choice of fresh vegetable retail outlets by developing-country urban consumers: The case of kale consumers in Nairobi, Kenya', European Journal of Development Research 24(3), 434-449. https://doi.org/10.1057/ejdr.2011.58

Peyton, S., Mosely, W. \& Battersby, J., 2015, 'Implications of supermarket expansion on urban food security in Cape Town, South Africa', African Geographical Review 34(1), 36-54. https://doi.org/10.1080/19376812.2014.1003307

Potts, D., 2008, 'The urban informal sector in sub-Saharan Africa: From bad to good (and back again?)', Development Southern Africa 25(2), 51-67. https://doi.org/ 10.1080/03768350802090527

Prain, G. \& Lee-Smith, D., 2010, 'Urban agriculture in Africa: What has been learned?', in G. Prain, N. Karanja \& D. Lee-Smith (eds.), African urban harvest Agriculture in the cities of Cameroon, Kenya and Uganda, pp. 13-38, Springer Science, New York.

Rajiv, R., 2010, Formal versus informal markets: Investing in agriculture markets based solution (Decision and policy analysis), International Centre for Tropical Agriculture, viewed 13 August 2015, from http://dapa.ciat.cgiar.org/formalversus-informal-markets/
Roesel, K. \& Grace, D., 2015, Food safety and informal markets: Animal products in sub-Saharan Africa, Routledge, Oxon.

Sahyoun, N.R., Zhang, X.L. \& Serdula, M.K., 2006, 'Barriers to the consumption of fruits and vegetables among older adults', Journal of Nutrition for the Elderly 24(4), 5-21. https://doi.org/10.1300/J052v24n04_03

Seto, K.C. \& Ramankutty, N., 2016, 'Hidden linkages between urbanization and food systems', Science 352, 943-945. https://doi.org/10.1126/science.aaf7439

Smart, J., Nel, E. \& Binns, T., 2015, 'Economic crisis and food security in Africa: Exploring the significance of urban agriculture in Zambia's Copperbelt province', Geoforum 65, 37-45. https://doi.org/10.1016/j.geoforum.2015.07.009

Statistics South Africa, 2011, Mafikeng statistics, viewed 09 December 2015, from http://www.statssa.gov.za/?page_id=993\&id=mafikeng-municipality

Statistics South Africa, 2015a, Quarterly Labour Force Survey - Quarter 4, 2014, Stats SA, Pretoria, viewed 12 November 2015, from http://www.statssa.gov.za/ publications/P0211/P02114thQuarter2014.pdf

Statistics South Africa, 2015b, Labour market dynamics in South Africa, 2014 report, Stats SA, Pretoria, viewed 13 November 2015, from http://www.statssa.gov. $\mathrm{za} / \mathrm{p} \mathrm{p}=4445$

Van Rooyen, C.J., Mavhandu, B.F. \& Van Schalkwyk, H.D., 1997, 'The informal food marketing system in urban environments: Case studies of Kagiso and Orange Farm' Development Southern Africa 14(3), 471-476. https://doi.org/10.1080/03768 359708439978

Weatherspoon, D.D. \& Reardon, T., 2003, 'The rise of supermarkets in Africa: Implications for agri-food systems and the rural poor', Development Policy Review 21(3), 333-355. https://doi.org/10.1111/1467-7679.00214

Wongprawmas, R., Canavari, M. \& Waisarayutt, C., 2014, 'Are Thai consumers willing to pay for food safety labels? Choice experiment of fresh produce', paper prepared for presentation at the EAAE congress, Agri-Food and Rural Innovations fo Healthier Societies, Ljubljana, Slovenia, 26-26 August. 